DOI: 10.2478/atd-2022-0007

\title{
Organizational Justice, Perceived Stress and Leader Support as Predictors of Teachers' Job Satisfaction
}

\author{
Hayriye Reyhan Çelik - Ömür Kaya Kalkan*
}

\begin{abstract}
Received: October 13, 2020; received in revised form: January 30, 2021;
\end{abstract}
accepted: February 1, 2021

\begin{abstract}
:
Introduction: Teachers' job satisfaction which has a positive effect on the quality of education, students, teachers and schools is significant for the successful functioning of schools. On the other hand, the increase in the level of dissatisfaction causes disciplinary problems, inefficiency, job dissatisfaction, alienation from the job, or leaving the job. Therefore, research on teachers' job satisfaction can help to understand the general and specific aspects of teachers' job satisfaction, which in turn this information can provide a scientific basis for solving problems.

Methods: The study uses quantitative research methodologies based on a correlational research. The research data obtained the convenience sampling method from 396 teachers who work for public schools in the province of Denizli in Turkey. Multiple regression was used for analysis.

Results: The results of the study showed that organizational justice, perceived stress and leadership support are all significant predictors of teachers' job satisfaction. The relative importance order of the specified variables in predicting teachers' job satisfaction is organizational justice, perceived stress and leader support, respectively. Predictor variables account for approximately $50.4 \%$ of the total variance in teachers' job satisfaction.

Discussion: Within the scope of the research, the relationships determined between job satisfaction, organizational justice, perceived stress and leader support are consistent with the results of the research conducted on teachers and other professional groups in the literature. Implications of the study results were discussed in detail.

Limitations: In addition to its contributions to the literature, the research also has some limitations. Basically, correlational research results can be useful to reveal the existing relationships between variables, but it should be emphasized that these relationships are not causal ones. Furthermore, the use of convenience sampling method among non-random sampling
\end{abstract}

\footnotetext{
* Hayriye Reyhan Çelik, Pamukkale University, Faculty of Education, Pamukkale, Turkey; hcelik103@posta.pau.edu.tr Ömür Kaya Kalkan, Pamukkale University, Faculty of Education, Pamukkale, Turkey; kayakalkan@pau.edu.tr
} 


\section{Acta Educationis Generalis \\ Volume 12, 2022, Issue 1}

methods can be considered as another limitation. However, the consistency of the relationships determined between the variables of the study with the existing literature indicates that the bias due to this limitation is relatively low.

Conclusion: The results of the study indicated that the order of relative importance in educational policies and practices that will take teachers' job satisfaction into account should be structured as organizational justice, perceived stress and leader support. However, it is thought that holistic approaches that include all variables can be more effective, since variables of organizational justice, perceived stress and leader support are significantly associated with teachers' job satisfaction.

Key words: teachers' job satisfaction, organizational justice, perceived stress, leadership support.

\section{Introduction}

Employee job satisfaction has been an intensive study area both for researchers and practitioners since the classic work of Hoppock (1935) was published. Job satisfaction is defined as the degree that employees like their jobs and different aspects of their jobs (Spector, 1997) or a pleasurable emotional state arising from evaluating their work (Locke, 1976). The concept of teachers' job satisfaction is defined as teachers' general attitudes and opinions towards their working conditions and professions (Hongying, 2007). The concepts of job satisfaction, organization justice, perceived stress and leader support are introduced below respectively.

\section{Theoretical background}

\subsection{Job satisfaction}

Job satisfaction is the result of employees' perception of how well their job delivers what is considered essential by them, and research showed that job satisfaction affects teachers' job enthusiasm (Weiqi, 2007). On an individual level, job satisfaction affects job enthusiasm and mental health of teachers whereas in terms of school administration teachers' job satisfaction is seen as a factor that affects the teaching, school quality and efficiency of school leadership (Hongying, 2007). Since job satisfaction is an attitudinal and dynamic concept, it can vary in the process due to its nature. In other words, since satisfaction level is an attitude formed by the employee's own perception, the effects of various factors may differ due to individual orientations (Toker, 2006). In literature, the factors that focus on the content of the profession (e.g., positive relationships with colleagues and students, diversity in the profession, etc.), generally lead to an increase in experienced job satisfaction. However, according to the extent that they have an effect, employment conditions (e.g., income, 


\section{Acta Educationis Generalis \\ Volume 12, 2022, Issue 1}

working hours, administrative burden, too much work, etc.) generally lead to a decrease in job satisfaction (Van Ham, Verhoeven, Groenier, Groothoff, \& De Haan, 2006). In this context, it is stated that teachers are generally delighted with internal factors such as interpersonal relations, self-fulfillment, social recognition and professional input, and not satisfied with other factors such as wage income, promotions, physical environments, student quality, educational social environment and job stress (Hongying, 2007). In addition to this, organizational factors; leader attitudes and behaviors (Karaköse \& Kocabaş, 2006), wage (Filiz, 2014; Göktaş, 2007), working conditions and promotion opportunities (Ayan, Kocacık, \& Karakuş, 2009; Liu \& Ramsey, 2008; Shen, Leslie, Spybrook, \& Ma, 2012; Taşdan \& Tiryaki, 2008), group factors; manager and colleague relations (Koruklu, Feyzioğlu, Özenoğlu-Kiremit, \& Aladağ, 2013; Tunacan \& Çetin, 2009), organizational and group factors (Özkalp \& Kirel, 1996) are significantly associated with job satisfaction.

\subsection{Organizational justice}

Organization justice is a concept that is typically used to define the role of justice in workplaces. This concept is primarily related to whether employees have a fair treatment at work and the ways how these findings can affect the other work-related variables (Moorman, 1991). While organizational justice was initially addressed in terms of the distributive justice dimension (origins from Adams' work; 1965) and procedural justice dimension (Thibaut \& Walker, 1975) in the literature (e.g., Folger \& Greenberg, 1985; Moorman, 1991), then the interactional justice dimension (Bies \& Moag, 1986) was introduced. The idea which states interactional justice consists of interpersonal and informational justice sub-dimensions started to be accepted (e.g., Cropanzano, Bowen, \& Gilliland, 2007; Greenberg, 1990, 1993). Distributive justice is about the perception of the most significant results (e.g., salary, promotion, shift, assignments and workplace discipline, etc.) by employees as fair in organizations and whether all employees are treated in the same way (CohenCharash \& Spector, 2001; Colquitt, Conlon, Wesson, Porter, \& Ng, 2001; Cropanzano et al., 2007). Procedural justice refers to the perceptions of employees regarding the fairness and accuracy of the procedures and policies used to achieve distributive justice (Colquitt et al., 2001; Greenberg, 1990). Interactional justice in the simplest sense refers to how one person treats another (Cropanzano et al., 2007). Interpersonal fairness generally refers to the degree at which employees are treated with courtesy, dignity and respect in the implementation of procedures or determination of results. Informational justice focuses on explanations given to people who pass on information about why procedures are used in a particular way or why results are being distributed in a particular way (Colquitt et al., 2001). Organizational justice is positively related to job satisfaction (Al-Zu'bi, 2010; DeConinck \& Stilwell, 2004; Kılıç, 2016; Eker, 2006; Özen-Kutanis \& Mesci, 2010; Netemeyer, Boles, McKee, \& 


\section{Acta Educationis Generalis \\ Volume 12, 2022, Issue 1}

McMurrian, 1997; Nojani, Arjmandnia, Afrooz, \& Rajabi, 2012; Yıldırım, 2007) and directly affects job satisfaction (Najafi, Noruzy, Azar, Nazari-Shirkouhi, \& Dalv, 2011). Besides, the communication and treatment of managers in the implementation of organizational justice also affect employees' perceptions of stress (Swandarujati, Nurfitri, \& Anggraeni, 2019). Moreover, organizational justice is associated with increased employee performance (Cohen-Charash \& Spector, 2001), job satisfaction and organizational commitment (Bağc1, 2013; Candan, 2014) and a decrease in turnover tendencies (Demircan-Çakar \& Yıldız, 2009). In addition to this, there is a positive and significant relationship between teachers' perceptions of organizational justice and job satisfaction (Altahayneh, Khasawneh, \& Abedalhafiz, 2014; Dundar \& Tabancali, 2012; Nojani et al., 2012; Zainalipour, Fini, \& Mirkamali, 2010).

\subsection{Perceived stress}

The amount of pleasure or job satisfaction any person gets while doing a job is affected by several factors (Cooper, Rout, \& Faragher, 1989). One of the factors affecting the job satisfaction of employees is stress (Bolin, 2007; Cooper et al., 1989; Hongying, 2007; Şanll, 2017; Weiqi, 2007; Toker, 2006; Yüksel, 2003). In general, stress is an unpleasant emotional and physiological condition that is caused by uncertainty or experiences beyond the employee's control and is considered harmful by employees (Swandarujati et al., 2019). Stress, which is a common problem today, has adverse effects on physiological and mental health (Lee, Joo, \& Choi, 2013). On the other hand, stress has a positive aspect (Aydin, 2004; Onay-Özkaya, Yakın, \& Ekinci, 2008). The concept stated as positive stress is a constructive value that increases the individual's motivation. For the teaching profession which is considered to be one of today's stressful professions, moderate stress helps to increase performance, while experiencing a high-level of stress causes harmful effects (Balaban, 2000). The stress encountered in the teaching profession has been conceptualized as teacher stress in the literature. Teacher stress can be defined as experiencing unpleasant negative emotions such as anger, anxiety, tension, disappointment, or depression that originated from some part of the teachers' work (Kyriacou, 2001). Teachers' stresses are attributable to negative school climate, inappropriate student behavior, maintaining discipline, time pressure and workload, coping with change, being evaluated by others, relationships with colleagues, self-esteem and status, role conflict and uncertainty, inadequate classroom resources, school management, poor working conditions and deficiencies in teachers' recognition of their profession (Boyle, Borg, Falzon, \& Baglioni, 1995; Kremer-Hayon \& Goldstein, 1990; Kyriacou, 2001).

\subsection{Leader support}

Leadership in education is crucial as it has the potential to affect both learning outcomes and relationships between teacher and student. This contributes to the 


\section{Acta Educationis Generalis \\ Volume 12, 2022, Issue 1}

creation and maintenance of an effective learning climate, the development and improvement of teamwork during educational process (Daučianskaitė \& Žydžiūnaitè, 2020). An essential indicator of leadership in education can be a leader support perceived by teachers in schools. Teachers develop some opinions on the leader's efforts for the welfare of the school. As suggested by Eisenberger, Stinglhamber, Vandenberghe, Sucharski and Rhoades (2002), teachers as employees perceive the leader's positive and negative behaviors towards them as an indicator of organizational support. In this context, leader support can be defined as the degree of support and interest that a person perceives from their immediate supervisor (Netemeyer et al., 1997). In the educational leadership literature, there are leadership types created with different perspectives. It can be said that the common point of these concepts, which are dealt with theoretically and empirically, is to increase student learning, to create a positive school climate based on open and honesty for student, teacher and leader learning and to include teachers in decision-making processes (Kılınç, 2016; Sancar, 2009). Leadership behaviors of school principals are significantly correlated with teachers' job satisfaction (Bogler, 2001; Hulpia et al., 2009; Sancar, 2009). A leader's support of employees is related to job satisfaction (Asgari, Mezginejad, \& Taherpour, 2020; Kale, 2015; Tsai, 2011) and has a determinant feature in increasing the employee's job satisfaction within the framework of the work process (Fernandez, 2008; Karadağ, Başaran, \& Korkmaz, 2009; Tanrıverdi \& Paşaoğlu, 2014; Tengilimoğlu \& Yiğit, 2005) and shows a strong relationship with leadership styles and organizational justice concepts (Çoğaltay, Karadağ, \& Bektas, 2014). In line with this, it is stated that such factors as giving opportunity teachers to explain their work to their colleagues, encourage them for quick and easy communication, praise teachers' work, empower teachers and include them in decision-making processes can increase teachers' job satisfaction (Lunenburg \& Ornstein, 2000).

It is seen that teachers' job satisfaction which has a positive effect on the quality of education, students, teachers and schools is significant for the successful functioning of schools (Michaelowa \& Wittmann, 2007). On the other hand, the increase in the level of dissatisfaction causes disciplinary problems, inefficiency, job dissatisfaction, alienation from the job, or leaving the job (Akınc1, 2002; Chen, 2010). Therefore, effective school principals pay attention to teachers' job satisfaction for the long-term efficiency (Güçlü, 2001).

Research on teachers' job satisfaction can help to understand the general and specific aspects of teachers' job satisfaction which in turn can provide a scientific basis for solving problems (Hongying, 2007). The existing literature reveals that the relationship between organizational justice, perceived stress, and leader support variables and job satisfaction is not evaluated together. In addition to revealing the relationships between the specified variables and determining the predicting levels of these variables on teachers' job satisfaction has the potential to contribute to the relevant literature. In this context, the 


\section{Acta Educationis Generalis \\ Volume 12, 2022, Issue 1}

purpose of the present study is to determine the levels of organizational justice, stress and leader support variables in predicting teachers' job satisfaction. Thus, it is aimed to provide empirical evidence in light of the information obtained in this research for education policymakers, practitioners and researchers.

\section{Method}

\subsection{Research design}

This study was mainly designed as a correlational research. Correlational research, which can also be described as a descriptive research type, is used to clarify our understanding of essential phenomena by determining the relationship between two or more variables. If there is a sufficiently high relationship between these variables, the score of one variable can be estimated by using the scores of other variables. Therefore, it can be evaluated as a predictive type of correlational research in terms of the current research objective (Fraenkel, Wallen, \& Hyun, 2011).

\subsection{Participants}

The population of the study consists of 14135 teachers in Denizli, Turkey in the academic year of 2018-2019. The sample of the study consists of 396 teachers working in 31 different branches in 231 state schools. $58.6 \%$ of the participants are female $(n=232)$ and $41.4 \%$ of the participants were male $(n=164)$ in the sample. The working time of the participants varies between 1-44 years. Within the scope of the present study, a convenience sampling method was preferred among non-random sampling methods. In much educational research, it is difficult, sometimes impossible, to select a completely random sample. In this case, researchers can choose the appropriate sampling method. However, this preferred sampling method may be biased (Fraenkel et al., 2011). The sample size adequacy for a completely random sample in population of 20000 people (with a 95\% confidence interval) is 377 (Cohen, Manion, \& Morrison, 2018). However, since a completely random sampling is not possible within the scope of the research, data collection tools were delivered to 23 different schools from 5 different districts in order to reduce the bias caused by the sampling method. In addition to this, efforts were made to reach as many participants as possible rather than the adequate sample size. Nevertheless, only 396 participants turned voluntarily back to data collection tools.

\subsection{Data collection tools}

Within the scope of the research, Minnessota Job Satisfaction Scale, Organizational Justice Scale, Perceived Stress Scale, Leader Support Scale and demographic information form prepared by the researchers were used as data collection tools. 


\section{Acta Educationis Generalis \\ Volume 12, 2022, Issue 1}

Minnessota Job Satisfaction Scale. The scale developed by Weiss, Dawis, England, and Lofquist (1967) was adapted to Turkish language by Oran (1989). The scale consists of 20 items that can be graded in 5-point Likert type. Cronbach's Alpha $(\mathrm{Cr} \alpha)$ reliability coefficient of the scale, in which internal satisfaction, external satisfaction and general satisfaction scores can be obtained, was reported as $\mathrm{Cr} \alpha=.83$. Yildırım (1996) reported the test-retest reliability coefficient of the scale as .76 and the internal consistency coefficient as .90 . Within the scope of the present study, the reliability coefficient of the scale was determined as $\operatorname{Cr} \alpha=.96$.

Organizational Justice Scale. The scale developed by Niehoff and Moorman (1993) was adapted to Turkish language by Ylldırım (2002). The scale consists of 20 items that can be graded in 5-point Likert type. The Turkish form of the scale consists of three sub-dimensions: distributive justice, procedural justice and interactional justice. In the original form of the scale, $\mathrm{Cr} \alpha=.74$ for distributive justice sub-dimension, $\operatorname{Cr} \alpha=.85$ for procedural justice subdimension and $\mathrm{Cr} \alpha=.92$ for interactional justice sub-dimension were reported (Niehoff \& Moorman, 1993). The Turkish form of the scale has $\mathrm{Cr} \alpha$ coefficients, distributive justice .81 , procedural justice .89 , and interactional justice .95 . The reliability coefficients obtained for the sub-dimensions of the scale with the test-retest reliability determination method are $.44, .65$ and .73 for distributive justice, procedural justice and interactional justice, respectively (Yildirım, 2002, 2007). Within the scope of the present study, $\mathrm{Cr} \alpha$ reliability coefficients for the sub-dimensions of the scale were determined as .85 for distributive justice, .92 for procedural justice and .97 for interactional justice.

Perceived Stress Scale. In the scale developed by Cohen, Kamarck and Mermelstein (1983), there are 14 items that can be graded in 5-Likert type. This scale also has two separate forms with 10 and 4 items. In the present study, the 10 -item form of the scale was preferred. The reliability coefficient of the scale, which was adapted into Turkish language by Örücü and Demir (2008), was reported as $\operatorname{Cr} \alpha=.82$ and test-retest reliability as .88 . The scale has a two-factor structure: perception of stress/discomfort and insufficient self-efficacy. The reliability coefficient of the scale was determined as $\mathrm{Cr} \alpha=.84$, in the current study.

Leader Support Scale. The scale developed by Netemeyer, Boles, McKee, and McMurrian (1997) consists of 5 items that can be graded in a 5-point Likert type. The reliability coefficient of the scale was reported as $\mathrm{Cr} \alpha=.87$. Later, the reliability coefficient of the scale used by Ackfeld and Coote (2005) was reported as $\operatorname{Cr} \alpha=.89$. The reliability coefficient of the scale, adapted to Turkish language by Çelik and Turunç (2010), is $\operatorname{Cr} \alpha=.95$. Within the scope of the 


\section{Acta Educationis Generalis \\ Volume 12, 2022, Issue 1}

present study, the reliability coefficient of the scale was determined as $\mathrm{Cr} \alpha=$ 97.

\subsection{Data analysis}

Mean (M), median (MED), mode (MOD), skewness coefficient (SC) and kurtosis coefficient $(\mathrm{KC})$ were used in reporting the descriptive statistics for scale scores. The Pearson correlation was used to determine the relationship between variables. Multiple regression analysis was used to determine the degree that organizational justice, perceived stress and leadership support variables predict teachers' job satisfaction.

\section{Results}

Descriptive statistics on teachers' job satisfaction, organizational justice, perceived stress and leader support variables are presented in Table 1.

Table 1

Descriptive statistics on research variables

\begin{tabular}{|c|c|c|c|c|c|}
\hline Variable & $\underline{M}$ & $\underline{M E D}$ & $M O D$ & $\underline{S C}$ & $\underline{K C}$ \\
\hline Job satisfaction & $7 \overline{7.26}$ & 78 & 80 & -.48 & .35 \\
\hline Organizational justice & 73.00 & 75 & 75 & -.39 & -.25 \\
\hline Perceived stress & 26.83 & 27 & 30 & -.24 & .30 \\
\hline Leader support & 18.23 & 20 & 20 & -.84 & -.23 \\
\hline
\end{tabular}

Table 1 shows that the $\mathrm{SC}$ and $\mathrm{KC}$ of teachers' job satisfaction, organizational justice, perceived stress, and leader support scale scores are within \pm 1 limits. These values which are within \pm 1 limits indicate that the scale total scores do not show an extreme deviation from the normal distribution (Cohen et al., 2011; Muthén \& Kaplan, 1985). After the variables in the data set provided the assumption of normality, Mahalanobis distances were calculated for the multivariate outlier analysis and the obtained values were compared with the critical value of chi-square $\chi^{2} 16.266$ for $\alpha=.001$ and degrees of freedom (df) 3 . All the values obtained from the scales are below this critical value. This indicates that there are no multivariate outliers in the data set (Tabachnick \& Fidell, 2007). The linearity and normality assumptions of the relationship between the predictor variables and the dependent variable (job satisfaction) were examined through graphics. The scatter plot obtained for standardized residual values and standardized predicted values defines a linear relationship and the points are collected around the axis. The histogram and normal distribution curves obtained for the standardized predicted values have approximately normal distribution (Interested readers can contact the corresponding author for more detailed information on the test of assumptions). 


\section{Acta Educationis Generalis \\ Volume 12, 2022, Issue 1}

In the multiple regression analysis, the correlation values between the predictor variables were examined in order to determine whether there was a multicollinearity problem between the predictor variables (see Table 2). For this purpose, variance ratio related to a predictor variable that unexplained by other predictor variables (Tolerance), variance inflation factor (VIF) and condition index (CI) values were examined (see Table 3 ).

\section{Table 2}

Correlation values for the variables

\begin{tabular}{|c|c|c|c|c|}
\hline & $\frac{\text { Job }}{\text { satisfaction }}$ & $\frac{\text { Organizational }}{\text { justice }}$ & $\frac{\text { Perceived }}{\text { stress }}$ & Leader support \\
\hline Job satisfaction & 1 & .70 & -.34 & .40 \\
\hline $\begin{array}{l}\text { Organizational } \\
\text { justice }\end{array}$ & & 1 & -.32 & .46 \\
\hline Perceived stress & & & 1 & -.20 \\
\hline Leader support & & & & 1 \\
\hline
\end{tabular}

When the bivariate correlations between the predictor variables and the dependent variable were examined, a positive and high level of relationship $(\mathrm{r}=.70)$ was found between organizational justice and job satisfaction, while controlling for other variables, this relationship was calculated as $r=.60$. While there was a negative and moderate relationship $(\mathrm{r}=-.34)$ between perceived stress and job satisfaction, this relationship was calculated as $\mathrm{r}=-.16$ when other variables were controlled. While there was a positive and moderate relationship $(\mathrm{r}=.40)$ between leader support and job satisfaction, this relationship was calculated as $\mathrm{r}=.12$ when other variables were controlled. Table 2 showed that the correlation values between organizational justice, perceived stress and leader support variables are below .90. These values show that there is no multicollinearity problem between the predictor variables (Tabachnick \& Fidell, 2007). Tolerance, VIF and CI values for the predictor variables are presented in Table 3.

Table 3

Multicollinearity statistics of the predictor variables

\begin{tabular}{lccc}
\hline \multicolumn{1}{c}{ Variable } & Tolerance & $\underline{V I F}$ & $\underline{C I}$ \\
Organizational justice & .74 & 1.36 & 6.52 \\
Perceived stress & .89 & 1.12 & 10.27 \\
Leader support & .79 & 1.27 & 19.44 \\
\hline
\end{tabular}

Table 3 shows that among the multicollinearity statistics related to organizational justice, perceived stress and leader support variables, Tolerance values are greater than .20, VIF values are lower than 10 and CI values are lower 


\section{Acta Educationis Generalis \\ Volume 12, 2022, Issue 1}

than 30. These values show that there is no multicollinearity problem among predictor variables (Büyüköztürk, 2011).

After examining the normality assumption of the data set, multivariate outliers, and multicollinearity problems, a multiple regression analysis was performed to determine the predictive levels of the variables on teachers' job satisfaction and the results are presented in Table 4.

Table 4

Multiple regression analysis results related to predicting job satisfaction of teachers

\begin{tabular}{lccccl}
\hline Variable & $\underline{B}$ & $\underline{B_{S E}}$ & $\underline{\beta}$ & $\underline{\underline{t}}$ & $\underline{p}$ \\
Constant & 44.798 & 3.608 & - & 12.415 & $.000^{* * * *}$ \\
Organizational justice & .487 & .033 & .612 & 14.763 & $.000^{* * *}$ \\
Perceived stress & -.253 & .080 & -.119 & -3.152 & $.002^{* *}$ \\
Leader support & .202 & .084 & .096 & 2.403 & $.017^{*}$ \\
$R=.71$ & $R^{2}=.504$ & & & & \\
$F_{(3,392)}=132.88$ & $p=.0000^{* * * *}$ & & & & \\
$* \mathrm{p}<.05, * * \mathrm{p}<.01, * * * \mathrm{p}<.001$ & & & &
\end{tabular}

Table 4 showed that the variables of organizational justice, perceived stress and leader support together give a high and significant relationship with teachers' job satisfaction scores, $\mathrm{R}=.71, \mathrm{R}^{2}=.504, \mathrm{p}<.01$. The specified three variables explained approximately $50.4 \%$ of the total variance in teachers' job satisfaction. Based on the standardized regression coefficients $(\beta)$, the relative order of importance of predictor variables on teachers' job satisfaction is organizational justice, perceived stress and leadership support, respectively. In addition to this, $\mathrm{t}$ test results for the significance of regression coefficients showed that organizational justice, perceived stress and leadership support are all significant predictors on teachers' job satisfaction.

\section{Discussion and conclusion}

The present study evaluated the roles of organizational justice, perceived stress, and leader support variables in predicting teachers' job satisfaction. The results of the study showed that organizational justice, perceived stress, and leader support were significant predictors of teachers' job satisfaction. The relative importance of the variables in predicting job satisfaction was organizational justice, perceived stress and leader support respectively, and the predictive variables explain about $50.4 \%$ of the total variance in teachers' job satisfaction. Within the scope of the study, the most crucial variable in predicting teachers' job satisfaction is organizational justice. In addition, there is a significant positive and high level relationship between teachers' job satisfaction and organizational justice. The results of this study show consistency with the 


\section{Acta Educationis Generalis \\ Volume 12, 2022, Issue 1}

findings of other studies on teacher samples (Altahayneh et al., 2014; Dundar \& Tabancali, 2012; Kılıç, 2016; Nojani et al., 2012; Tanrıverdi \& Paşaoğlu, 2014; Zainalipour et al., 2010) and with the findings of studies on other profession samples (Al-Zu'bi, 2010; DeConinck \& Stilwell, 2004; Kılıç, 2016; Eker, 2006; Özen-Kutanis \& Mesci, 2010; Netemeyer et al., 1997; Yıldırım, 2007).

Organizational justice generally refers to the perceptions of employees on whether they are treated fairly in the workplace (Moorman, 1991), the distribution of the organization results (e.g. salary, promotion, workplace discipline, etc.) fairly (Cohen-Charash \& Spector, 2001; Colquitt et al., 2001; Cropanzano et al., 2007), the fairness and accuracy of the procedures and policies used for achieving these results, and the degree of courtesy, dignity and respect shown to them during these practices (Colquitt et al., 2001; Greenberg, 1990). In this sense, teachers care about the fairness of the decisions taken at school, the fairness of the procedures and policies, and the behaviors of the administrators towards them and other employees. It is reported that teacher job satisfaction has a positive effect on the quality of education, students, teachers and schools (Michaelowa \& Wittmann, 2007), increases employee performance and organizational commitment (Bağc1, 2013; Candan, 2014; Cohen-Charash \& Spector, 2001), and reduces turnover tendencies (Demircan-Çakar \& Yıldız, 2009). Considering these positive effects as well as the current research results, it may be suggested to the administrators and policymakers that they should prioritize practices aimed at ensuring and improving organizational justice (e.g., being fair in syllabus, shifts, rewarding and disciplinary procedures, ensuring active participation of teachers in decision-making processes, providing trainings to develop effective communication skills, positive feedback etc.).

Within the scope of the research, the second priority variable in predicting job satisfaction is perceived stress. Teachers attached more importance to organizational justice than a personal variable such as perceived stress. This result is consistent with some research results in the literature (Adera \& Bullock, 2010; Turunç et al., 2010) and can be addressed from two different points of view. First, employees spend most of their lives in the workplace. Employees who have a positive perception of organizational justice have positive perceptions of the organization, high levels of success, and high performance indicators (İyigün, 2012). Therefore, positive perception of organizational justice can alleviate the adverse effects of personal variables such as stress on individuals. The second is the relationship between job satisfaction and life satisfaction. Life satisfaction generally refers to the whole of individuals' perceptions of their own lives (Avşaroğlu, Deniz, \& Kahraman, 2005). Considering that employees with high job satisfaction may also have high life satisfaction, it can be stated that they cope with the adverse effects of stress. Ünal, Karlıdağ, and Yoloğlu (2001) stated that job satisfaction is the variable that has the most significant effect on life satisfaction. On the other hand, low job satisfaction in the teaching profession results in absenteeism or job change. 


\section{Acta Educationis Generalis \\ Volume 12, 2022, Issue 1}

Absenteeism in the teaching profession such as getting permission and medical report, not being able to conduct educational activities results in cuts in wages. In addition to this, changing jobs is seen as changing schools or changing professions. However, changing a profession is related to the economic and employment level of the country, individuals may not consider to change their jobs even if their job satisfaction is low (Özkalp \& Kırel, 1996). If teachers do not change jobs, this may cause them to encounter frequent mid-career crisis (Kyriacou, 2001). The stress seen in the individual as a result of job dissatisfaction can affect the relationships with the leader and colleagues and the perceptions towards the organization. In addition, the communication and treatment of managers in the implementation of organizational justice also affects employees' perceptions about stress (Swandarujati et al., 2019). The current study revealed that a significant negative and moderate relationship was found between the teachers' perceived stress and job satisfaction. Similar results have been reported in studies conducted with teachers (Hassard et al., 2017) and other samples (Sert et al., 2014). The negative relationship between teachers' perceived stress and job satisfaction indicates that practices aimed at reducing teachers' perceived stress can have positive effects on job satisfaction. In addition, ensuring and developing organizational justice in schools can make positive contributions to decrease the stress perceived by teachers and increase their job satisfaction. Considering that teaching is among professions that experience the highest level of work stress (Stoeber \& Rennert, 2008), school administrators should prefer approaches based on courtesy and respect in their communication with teachers, consider stress, job satisfaction and organizational justice relations, and in this sense, practices that will reduce the stress of employees may be suggested to turn.

According to the relative importance level, leader support comes after organizational justice and perceived stress variables in predicting teachers' job satisfaction. Since the multidimensional structure of organizational justice (i.e. distributive, transactional and interactional justice) evaluates all transactions and processes within the organization, this result can be explained by evaluating the attitudes and behaviors of leaders towards the organization by employees through the scope of organizational justice. Çoğaltay et al. (2014) reported that educational leadership has a moderate positive effect on organizational justice. Additionally, it was found that there was a significant positive and moderate relationship between leader support and job satisfaction. As suggested by the results of the studies focusing on various occupational groups the leader support has a positive impact on professional development, empowerment and job satisfaction (Ackfeldt \& Coote, 2005; Fernandez, 2008; Kale, 2015; Tengilimoğlu \& Yiğit, 2005). Within the scope of the research, a significant negative and moderate relationship was determined between leader support and perceived stress. Similarly, Osunka and Unachukwu (2020) reported a negative relationship between leadership support and teachers' perceptions of work- 


\section{Acta Educationis Generalis \\ Volume 12, 2022, Issue 1}

related stress. In general, the inability of the principals to establish a positive and constructive colleague relationship with the staff creates an atmosphere of insecurity and anxiety that can expose teachers to high stress (Lambersky, 2016). School principals' attention to the needs of teachers and providing them support may help to increase the job satisfaction (Ackfeldt \& Coote, 2005). Therefore, school administrators' providing teachers with a working environment in which they feel safe and can express themselves comfortably, taking into account the needs of teachers will help teachers to make positive contributions to their job satisfaction levels.

In addition to its contributions to the literature, the research also has some limitations. Basically, correlational research results can be useful to reveal the existing relationships between variables, but it should be emphasized that these relationships are not causal ones. Furthermore, the use of convenience sampling method among non-random sampling methods can be considered as another limitation. However, the consistency of the relationships determined between the variables considered within the scope of the study with the existing literature indicates that the bias due to this limitation is relatively low.

As a result, it can be suggested that the order of relative importance in educational policies and practices that will take teachers' job satisfaction into account should be structured as organizational justice, perceived stress and leader support. However, it is thought that holistic approaches that include all variables can be more effective, since variables of organizational justice, perceived stress and leader support are significantly associated with teachers' job satisfaction. On the other hand, the specified variables explain $50 \%$ of the variability in teachers' job satisfaction and there is still a 50\% part that cannot be explained. Therefore, it can be suggested to future researchers to conduct research by choosing variables for this unexplained part of teachers' job satisfaction. In addition, since the current research has been carried out with teachers working in the public sector, different results can be obtained with a study involving teachers working in the private sector.

\section{Acknowledgement}

A part of this study was presented as an oral presentation at the 2nd International Congresses on New Horizons in Education and Social Sciences held on 18-19 June 2019 in Istanbul, Turkey. 


\section{Acta Educationis Generalis \\ Volume 12, 2022, Issue 1}

\section{References}

Ackfeldt, A. L., \& Coote, L. V. (2005). A study of organizational citizenship behaviors in a retail setting. Journal of Business Research, 58(2), 151-159. https://doi.org/10.1016/s01482963(03)00110-3

Adams, J. S. (1965). Inequity in social exchange. Advances in experimental social psychology, 2, 267-299.

Adera, B. A., \& Bullock, L. M. (2010). Job stressors and teacher job satisfaction in programs serving students with emotional and behavioral disorders. Emotional and behavioural difficulties, 15(1), 5-14. https://doi.org/10.1080/13632750903512365

Akıncı, Z. (2002). Turizm sektöründe işgören iş tatminini etkileyen faktörler: beş yıldızlı konaklama işletmelerinde bir uygulama. Akdeniz IIIBF Dergisi, 4, 1-25.

Altahayneh, Z. L., Khasawneh, A., \& Abedalhafiz, A. (2014). Relationship between organizational justice and job satisfaction as perceived by Jordanian physical education teachers. Asian Social Science, 10(4), 131-138. https://doi.org/10.5539/ass.v10n4p131

Al-Zu'bi, H. A. (2010). A study of relationship between organizational justice and job satisfaction. International Journal of Business and Management, 5(12), 102. https://doi.org/10.553 9/ijbm.v5n12p102

Asgari, A., Mezginejad, S., \& Taherpour, F. (2020). The role of leadership styles in organizational citizenship behavior through the mediation of perceived organizational support and job satisfaction. Innovar, 30(75), 87-98. https://doi.org/10.15446/innovarv30n75.83259

Avşaroğlu, S., Deniz, M. E., \& Kahraman, A. (2005). Teknik öğretmenlerde yaşam doyumu iş doyumu ve mesleki tükenmişlik düzeylerinin incelenmesi. Selçuk Üniversitesi Sosyal Bilimler Enstitüsü Dergisi, 14, 115-129.

Ayan, S., Kocacık, F., \& Karakuş, H. (2009). Lise öğretmenlerinin iş doyumu düzeyi ile bunu etkileyen bireysel ve kurumsal etkenler: Sivas merkez ilçe örneği. Anadolu Psikiyatri Dergisi, 10(1), 18-25.

Aydın, Ş. (2004). Otel işletmelerinde örgütsel stres faktörleri. Dokuz Eylül Üniversitesi Sosyal Bilimler Enstitüsü Dergisi, 4, 1-9.

Bağc1, Z. (2013). Çalışanların örgütsel adalet algılarının örgütsel bağlllıkları üzerindeki etkisi: Tekstil sektöründe bir inceleme. Uluslararası Yönetim İktisat ve İşletme Dergisi, 9(19), 163184. https://doi.org/10.11122/ijmeb.2013.9.19.273

Balaban, J. (2000). Temel eğitimde öğretmenlerin stres kaynakları ve başa çıkma teknikleri. Pamukkale Üniversitesi Eğitim Fakültesi Dergisi, 7(7), 188-195.

Bies, R. J., \& Moag, J. F. (1986). Interactional justice: Communication criteria of fairness. In R. J. Lewicki, B. H. Sheppard, \& M. H. Bazerman (Eds.), Research on Negotiations in Organizations. Vol. 1, (pp. 43-55). Greenwich, CT: JAI Press.

Bogler, R. (2001). The influence of leadership style on teacher job satisfaction. Educational Administration Quarterly, 37(5), 662-683. https://doi.org/10.1177/00131610121969460

Bolin, F. (2007). A study of teacher job satisfaction and factors that influence it. Chinese Education \& Society, 40(5), 47-64. https://doi.org/10.2753/CED1061-1932400506

Boyle, G. J., Borg, M. G., Falzon, J. M. \& Baglioni, Jr. A. J. (1995). A structural model of the dimensions of teacher stress. British Journal of Educational Psychology, 65(1), 49-67. https://doi.org/10.1111/j.2044-8279.1995.tb01130.x

Büyüköztürk, Ş. (2011). Sosyal bilimler için veri analizi el kitabı (13 ${ }^{\text {th }}$ edition). Ankara: Pegem Akademi.

Candan, H. (2014). Çalışanların örgütsel adalet ve örgütsel güven algılamalarının örgütsel bağl1lı̆ga etkisi: bir kamu kurumu üzerinde araştırma. Gaziantep Üniversitesi Sosyal Bilimler Dergisi, 13(4), 889-917.

Chen, J. (2010). Chinese middle school teacher job satisfaction and its relationships with teacher moving. Asia Pacific Education Review, 11(3), 263-272. https://doi.org/10.1007/s12564010-9085-1 


\section{Acta Educationis Generalis \\ Volume 12, 2022, Issue 1}

Cohen, S., Kamarck, T., \& Mermelstein, R. (1983). A global measure of perceived stress. Journal of health and social behavior, 385-396. https://doi.org/10.2307/2136404

Cohen, L., Manion, L., \& Morrison, K. (2018). Research methods in education. NY: Routledge.

Cohen-Charash, Y., \& Spector, P. E. (2001). The role of justice in organizations: A metaanalysis. Organizational Behavior and Human Decision Processes, 86(2), 278-321. https://doi.org/10.1006/obhd.2001.2958

Colquitt, J. A., Conlon, D. E., Wesson, M. J., Porter, C. O., \& Ng, K. Y. (2001). Justice at the millennium: a meta-analytic review of 25 years of organizational justice research. Journal of Applied Psychology, 86(3), 425-445. https://doi.org/10.1037/0021-9010.86.3.425

Cooper, C. L., Rout, U., \& Faragher, B. (1989). Mental health, job satisfaction, and job stress among general practitioners. British Medical Journal, 298, 366-370. https://doi.org/10.1136/ bmj.298.6670.366

Cropanzano, R., Bowen, D. E., \& Gilliland, S. W. (2007). The management of organizational justice. Academy of Management Perspectives, 21(4), 34-48. https://doi.org/10.5465/amp. 2007.27895338

Çoğaltay, N., Karadağ, E., \& Bektas, F. (2014). School leadership and organizational justice: A meta-analysis with Turkey representative sample. International Journal of Education, 6(1), 49-60. https://doi.org/10.5296/ije.v6i1.4865

Çelik, M., \& Turunç, Ö. (2010). Lider desteğinin çalışanların iş-aile yaşam çatışması ve iş performansına etkisi: Savunma sektöründe bir araştırma. Çukurova Üniversitesi Iktisadi ve İdari Bilimler Fakültesi Dergisi, 14(1), 19-41.

Daučianskaitè, A., \& Žydžiūnaitė, V. (2020). Differences and similarities between coaching, instructional and educational leadership styles. Acta Educationis Generalis, 10(3), 87-100. https://doi.org/10.2478/atd-2020-0022

DeConinck, J. B., \& Stilwell, C. D. (2004). Incorporating organizational justice, role states, pay satisfaction and supervisor satisfaction in a model of turnover intentions. Journal of Business Research, 57(3), 225-231. https://doi.org/10.1016/s0148-2963(02)00289-8

Demircan-Çakar, N., \& Yıldız, S. (2009). Örgütsel adaletin is tatmini üzerindeki etkisi: Algıllanan örgütsel destek" bir ara değişken mi? Electronic Journal of Social Sciences, 8(28), 68-90.

Dundar, T., \& Tabancali, E. (2012). The relationship between organizational justice perceptions and job satisfaction levels. Procedia-Social and Behavioral Sciences, 46, 5777-5781. https://doi.org/10.1016/j.sbspro.2012.06.513

Eisenberger, R., Stinglhamber, F., Vandenberghe, C., Sucharski, I. L., \& Rhoades, L. (2002). Perceived supervisor support: Contributions to perceived organizational support and employee retention. Journal of Applied Psychology, 87(3), 565-573. https://doi.org/10.1037/0021-9010.87.3.565

Eker, G. (2006). Örgütsel adalet algısı boyutları ve iş doyumu üzerindeki etkileri (Unpublished doctoral thesis). İzmir: Dokuz Eylül Üniversitesi.

Fernandez, S. (2008). Examining the effects of leadership behavior on employee perceptions of performance and job satisfaction. Public Performance \& Management Review, 32(2), 175205. https://doi.org/10.2753/PMR1530-9576320201

Filiz, Z. (2014). Öğretmenlerin iș doyumu ve tükenmişlik düzeylerinin incelenmesi. Uluslararası Yönetim İktisat ve Işsletme Dergisi, 10(23), 157-172. https://doi.org/10.17130/ijmeb.2014.10 .23 .437

Folger, R., \& Greenberg, J. (1985). Procedural justice: An interpretive analysis of personnel systems. In K. M. Rowland, \& G. R. Ferris (Eds.), Research in Personnel and Human Resource Management. Vol. 3 (pp. 141-183). Greenwich, CT: JAI Press.

Fraenkel, J. R., Wallen, N., \& Hyun, H. (2011). How to design and evaluate research in education. NY: McGraw Hill.

Göktaş, Z. (2007). Balıkesir ilindeki beden eğitimi öğretmenlerinin iş doyumu. Niğde Üniversitesi Beden Eğitimi ve Spor Bilimleri Dergisi, 1(1), 13-26. 


\section{Acta Educationis Generalis \\ Volume 12, 2022, Issue 1}

Greenberg, J. (1990). Employee theft as a reaction to underpayment inequity: The hidden cost of pay cuts. Journal of Applied Psychology, 75, 561-568. https://doi.org/10.1037/00219010.75.5.561

Greenberg, J. (1993). The social side of fairness: Interpersonal and informational classes of organizational justice. In R. Cropanzano (Ed.), Justice in the workplace: Approaching Fairness in Human Resource Management (pp. 79-103). Hillsdale, NJ: Erlbaum.

Güçlü, N. (2001). Stres yönetimi. Gazi Üniversitesi Gazi Eğitim Fakültesi Dergisi, 21(1), 91-109.

Hassard, J., Teoh, K., \& Cox, T. (2017). Organizational uncertainty and stress among teachers in Hong Kong: Work characteristics and organizational justice. Health promotion international, 32(5), 860-870. https://doi.org/10.1093/heapro/daw018

Høigaard, R., Giske, R., \& Sundsli, K. (2012). Newly qualified teachers' work engagement and teacher efficacy influences on job satisfaction, burnout, and the intention to quit. European Journal of Teacher Education, 35(3), 347-357. https://doi.org/10.1080/02619768.2011. 633993

Hongying, S. (2007). Literature review of teacher job satisfaction. Chinese Education \& Society, 40(5), 11-16. https://doi.org/10.2753/CED1061-1932400502

Hoppock, R. (1935). Job satisfaction. New York: Harper \& Row.

Hulpia, H., Devos, G., \& Rosseel, Y. (2009). The relationship between the perception of distributed leadership in secondary schools and teachers' and teacher leaders' job satisfaction and organizational commitment. School Effectiveness and School Improvement, 20(3), 291317. https://doi.org/10.1080/09243450902909840

İyigün, N. Ö. (2012). Örgütsel adalet: Kuramsal bir yaklaşım. İstanbul Ticaret Üniversitesi Sosyal Bilimler Dergisi 11(21), 49-64.

Kale, E. (2015). Lider desteği ve iş arkadaşları desteğinin iş performansı üzerine etkileri: iş tatmini ve yaşam tatmininin aracı rolü. International Journal of Economic \& Administrative Studies, 7(14), 103-119. https://doi.org/10.18092/ijeas.03564

Karadağ, E., Başaran, A., \& Korkmaz, T. (2009). İlköğretim okulu öğretmenlerinin algıladıkları liderlik biçimleri ile iş doyumları arasındaki ilişki. Balıkesir Üniversitesi Sosyal Bilimler Enstitüsü Dergisi, 12(21), 32-45.

Karaköse, T., \& Kocabaş, İ. (2006). Özel ve devlet okullarında öğretmenlerin beklentilerinin iş doyumu ve motivasyon üzerine etkileri. Eğitimde Kuram ve Uygulama, 2(1), 3-14.

Kılıç, Y. (2016). Lise öğretmenlerinin örgütsel adalet ve iş doyumu algıları arasındaki ilişki düzeyleri. Dicle Üniversitesi Ziya Gökalp Eğitim Fakültesi Dergisi, (28), 259-267. https://doi.org/10.14582/DUZGEF.727

Kılınç, A. Ç. (2016). Çağdaş liderlik yaklaşımları. In N. Güçlü, \& S. Koşar (Eds.), Eüitim Yönetiminde Liderlik Teori Araştırma ve Uygulama (pp. 69-89). Ankara: Pegem Akademi.

Koruklu, N., Feyzioğlu, B., Özenoğlu-Kiremit, H., \& Aladağ, E. (2013). Öğretmenlerin iş doyumu düzeylerinin bazı değişkenlere göre incelenmesi. Mehmet Akif Ersoy Üniversitesi Eğitim Fakültesi Dergisi, 1(25), 119-137.

Kremer-Hayon, L., \& Goldstein, Z. (1990). The inner world of Israeli secondary school teachers: Work centrality, job satisfaction and stress. Comparative Education, 26(2-3), 284-298. https://doi.org/10.1080/0305006900260210

Kyriacou, C. (2001). Teacher stress: Directions for future research. Educational Review, 53(1), 2735. https://doi.org/10.1080/00131910120033628

Lambersky, J. (2016). Understanding the human side of school leadership: Principals' impact on teachers' morale, self-efficacy, stress, and commitment. Leadership and Policy in Schools, 15(4), 71-78. https://doi.org/10.1080/15 700763.2016.1181188

Lee, J. S., Joo, E. J., \& Choi, K. S. (2013). Perceived stress and self-esteem mediate the effects of work-related stress on depression. Stress and Health, 29(1), 75-81. https://doi.org/10.1002/ smi. 2428 


\section{Acta Educationis Generalis \\ Volume 12, 2022, Issue 1}

Liu, X. S., \& Ramsey, J. (2008). Teachers' job satisfaction: Analyses of the teacher follow-up survey in the United States for 2000-2001. Teaching and Teacher Education, 24(5), 11731184. https://doi.org/10.1016/j.tate.2006.11.010

Locke E., A. (1976). The nature and causes of job satisfaction. In M. D. Dunnette (Ed.), Handbook of Industrial and Organizational Behavior (pp. 1297-1343). Chicago: Rand Mc Nally.

Lunenburg, F. C., \& Ornstein, A. C. (2011). Educational administration: Concepts and practices. Belmont: Wadsworth, Cengage Learning.

Michaelowa, K., \& Wittmann, E. (2007). Cost, satisfaction, and achievement of primary education evidence from Francophone Sub-Saharan Africa. Journal of Development Areas, 41(1), 5178.

Moorman, R. H. (1991). Relationship between organizational justice and organizational citizenship behaviors: Do fairness perceptions influence employee citizenship? Journal of Applied Psychology, 76(6), 845-855. https://doi.org/10.1037/0021-9010.76.6.845

Muthén, B., \& Kaplan, D. (1985). A comparison of some methodologies for the factor analysis of non-normal Likert variables. British Journal of Mathematical and Statistical Psychology, 38(2), 171-189.

Najafi, S., Noruzy, A., Azar, H. K., Nazari-Shirkouhi, S., \& Dalv, M. R. (2011). Investigating the relationship between organizational justice, psychological empowerment, job satisfaction, organizational commitment and organizational citizenship behavior: An empirical model. African Journal of Business Management, 5(13), 5241-5248.

Netemeyer, R. G., Boles, J. S., McKee, D. O., \& McMurrian, R. (1997). An investigation into the antecedents of organizational citizenship behaviors in a personal selling context. Journal of Marketing, 61(3), 85-98. https://doi.org/10.2307/1251791

Niehoff, B. P., Moorman, R. H. (1993). Justice as a mediator of the relationship between methods of monitoring and organizational citizenship behavior. Academy of Management Journal, 36(3), 527-556. https://doi.org/10.2307/256591

Nojani, M. I., Arjmandnia, A. A., Afrooz, G. A., \& Rajabi, M. (2012). The study on relationship between organizational justice and job satisfaction in teachers working in general, special and gifted education systems. Procedia-Social and Behavioral Sciences, 46, 2900-2905. https://doi.org/10.1016/j.sbspro.2012.05.586

Onay-Özkaya, M., Yakın, V., \& Ekinci, T. (2008). Stres düzeylerinin çalışanların iş doyumu üzerine etkisi Celal Bayar Üniversitesi çalışanları üzerine ampirik bir araştırma. Yönetim ve Ekonomi: Celal Bayar Üniversitesi İktisadi ve İdari Bilimler Fakültesi Dergisi, 15(1), 163179.

Oran-Başkaya, N. (1989), Job Satisfaction of a Group of Academic Staff in Marmara University (Unpublished master's thesis). İstanbul: Marmara Üniversitesi.

Osunka, E. C., \& Unachukwu, G. O. (2020). Relationship between principals' transformational and directive ethical leadership behaviour and teachers' job related stress in secondary schools in Enugu State, Nigeria. European Journal of Education Studies, (7)1, 115-124. https://doi.org/10.5281/zenodo.3698221

Örücü, M. Ç., \& Demir, A. (2008). Psychometric evaluation of perceived stress scale for Turkish university students. Stress and Health: Journal of the International Society for the Investigation of Stress, 25(1), 103-109. https://doi.org/10.1002/smi.1218

Özen-Kutanis, R., \& Mesci, M. (2010). Örgütsel adaletin çalışanların iş tatminine etkisi: turizm alanında eğitim veren bir yükseköğretim kurumuna yönelik bir örnek olay çalışması. Sakarya Üniversitesi İ̈BF Sosyal ve Ekonomik Araştırmalar Dergisi, 10(19), 527-552.

Özkalp, E., \& Kırel, Ç. (1996). Örgütsel Davranış. Anadolu Üniversitesi Yayınları.

Sancar, M. (2009). Leadership behaviors of school principals in relation to teacher job satisfaction in north Cyprus. Procedia-Social and Behavioral Sciences, 1(1), 2855-2864. https://doi.org/10.1016/j.sbspro.2009.01.508

Selye H. (1976) Stress without Distress. In G. Serban (Ed.), Psychopathology of Human Adaptation. Boston, MA: Springer. https://doi.org/10.1007/978-1-4684-2238-2_9 


\section{Acta Educationis Generalis \\ Volume 12, 2022, Issue 1}

Sert, A., Elçi, M., Uslu, T., \& Şener, İ. (2014). The effects of organizational justice and ethical climate on perceived work related stress. Procedia Social and Behavioral Sciences, 150(15), 1187-1198. https://doi.org/10.1016/j.sbspro.2014.09.134

Shen, J., Leslie, J. M., Spybrook, J. K., \& Ma, X. (2012). Are principal background and school processes related to teacher job satisfaction? A multilevel study using schools and staffing survey 2003-04. American Educational Research Journal,49(2), 200-230. https://doi.org/10.3102/0002831211419949

Spector, P. (1997). Job satisfaction: Application, assessment, causes, and consequences (Vol. 3). Thousand Oaks: Sage Publications. https://doi.org/10.4135/9781452231549

Stearns, E., Banerjee, N., Mickelson, R., \& Moller, S. (2014). Collective pedagogical teacher culture, teacher-student ethno-racial mismatch, and teacher job satisfaction. Social Science Research, 45, 56-72. https://doi.org/10.1016/j.ssresearch.2013.12.011

Stoeber, J., \& Rennert, D. (2008). Perfectionism in school teachers: Relations with stress appraisals, coping styles, and burnout. Anxiety, Stress, and Coping, 21(1), 37-53. https://doi.org/10.1080/10615800701742461

Swandarujati, M., Nurfitri, T., \& Anggraeni, A. I. (2019). Effect of organizational justice on stress with work-family conflict as a mediating variable. Journal of Research in Management, 2(4), 11-20. https://doi.org/10.33830/tjeb.v1i1.760

Şanlı, Ö. (2017). Öğretmenlerin algılanan stres düzeylerinin çeşitli değişkenler açısından incelenmesi. Electronic Journal of Social Sciences, 16(61), 385-396. https://doi.org/10.17755/esosder.304681

Tabachnick, B. G., \& Fidell, L. S. (2007). Using multivariate statistics. Boston, MA: Pearson Education.

Tanrıverdi, H., \& Paşaoğlu, S. (2014). Dönüşümcü liderlik, örgütsel adalet ve iş tatmini arasındaki ilişkileri belirlemeye yönelik okul öncesi öğretmenleri üzerinde bir araştırma. Electronic Journal of Social Sciences, 13(50), 274-293. https://doi.org/10.17755/esosder.71721

Taşdan, M., \& Tiryaki, E. (2008). Özel ve devlet ilköğretim okulu öğretmenlerinin iş doyumu düzeylerinin karş1laştırılması. Eğitim ve Bilim, 33(147), 54-70.

Tengilimoğlu, D., \& Yiğit, A. (2005). Hastanelerde liderlik davranışlarının personel iş doyumuna etkisini belirlemeye yönelik bir alan çalışması. Hacettepe Sağlık İdaresi Dergisi, 8(3), 374400.

Thibaut, J., \& Walker, L. (1975). Procedural justice: A psychological analysis. Hillsdale, NJ: Erlbaum Associates. https://doi.org/10.2307/1371953

Toker, B. (2006). Konaklama işletmelerinde işgören motivasyonu ve motivasyonun iş doyumuna etkileri İzmir'deki 5 ve 4 yllduzl otellere yönelik bir uygulama (Unpublished doctoral dissertation). İzmir: Dokuz Eylül Üniversitesi.

Tsai, Y. (2011). Relationship between organizational culture, leadership behavior and job satisfaction. BMC Health Services Research, 11(1), 98. https://doi.org/10.1186/1472-696311-98

Tunacan, S., \& Çetin, C. (2009). Lise öğretmenlerinin iş doyumunu etkileyen faktörlerin tespitine ilişkin bir araştırma. Marmara Üniversitesi Atatürk Ĕgitim Fakültesi Eğitim Bilimleri Dergisi, 29(29), 155-172.

Turunç, Ö., Tabak, A., Şeşen, H., \& Türkyılmaz, A. (2010). Çalışma yaşamı kalitesinin prosedür adaleti, iş tatmini, iş stresi ve işten ayrılma niyetine etkisi. The Journal of Industrial Relations and Human Resources, 12(3), 77-96. https://doi.org/10.4026/1303-2860.2010. 146.x

Ünal, S., Karlıdağ, R., \& Yoloğlu, S. (2001). Hekimlerde tükenmişlik ve iş doyumu düzeylerinin yaşam doyumu düzeyleri ile ilişkisi. Klinik Psikiyatri, 4(2), 113-118.

Van Ham, I., Verhoeven, A. A., Groenier, K. H., Groothoff, J. W., \& De Haan, J. (2006). Job satisfaction among general practitioners: a systematic literature review. The European Journal of General Practice, 12(4), 174-180. https://doi.org/10.1080/13814780600994376 


\section{Acta Educationis Generalis \\ Volume 12, 2022, Issue 1}

Weiqi, C. (2007). The structure of secondary school teacher job satisfaction and its relationship with attrition and work enthusiasm. Chinese Education \& Society, 40(5), 17-31. https://doi.org/10.2753/ced1061-1932400503

Weiss, D. J., Dawis, R. V., England, G. W., \& Lofquist, L. H. (1967). Manual for the Minnesota Questionnaire. Minnesota Studies in Vocational Rehabilitation: XXII. Minneapolis: University of Minnesota, Industrial Relations Center, Work Adjustment Project.

Yıldırım, F. (1996), Banka çalısanlarında is doyumu ve algılanan rol çatısması ile tükenmislik arasındaki ilişki (Unpublished Master's thesis). Ankara: Hacettepe Üniversitesi,.

Yıldırım, F. (2002). Çalışma yaşamında örgüte bağlllık ve örgütsel adalet ilişkisi. (Unpublished doctoral thesis). Ankara: Ankara Üniversitesi Sosyal Bilimler Enstitüsü.

Yıldırım, F. (2007). İş doyumu ile örgütsel adalet ilişkisi. Ankara Üniversitesi SBF Dergisi, 62(1), 253-278.

Yüksel, İ. (2003). İş stresi, işe bağl1lık ve iş doyumu arasındaki ilişkinin analizi (Teknisyenlere yönelik bir uygulama). Atatürk Üniversitesi İktisadi ve İdari Bilimler Dergisi, 17(1), 213224.

Zainalipour, H., Fini, A. A. S., \& Mirkamali, S. M. (2010). A study of relationship between organizational justice and job satisfaction among teachers in Bandar Abbas middle school. Procedia-Social and Behavioral Sciences, 5, 1986-1990. https://doi.org/10.1016/ j.sbspro.2010.07.401 